\title{
AN ANALYSIS OF SMES MARKET IN HISTORY OF AZERBAIJAN
}

\author{
Jamila Hasanova Vagif ${ }^{1, *}$ \\ Azerbaijan State University of Economics (UNEC), Baku, the Republic of Azerbaijan
}

\begin{abstract}
Research background: World experience shows that small and medium business in a civilized form is an important condition for the restoration of not only the economy. Periods of recession, stagnation and stabilization at a time when small and medium enterprises are the acceptable form of activity were observed.

Purpose of the article: The purpose of the study is to identify the weaknesses of small and medium enterprises in the local market, to analyze the main stages of development of such enterprises in Azerbaijan.

The research database includes works on the issues of local and foreign authors, decisions of the Cabinet of Ministers and the Ministry of Economy of Azerbaijan, normative-legal acts, statistical materials. The results will serve as the basis for further actions- the formation of innovative databases for data processing and analysis, the correct creation of the management structure of many business objects, the support of know-how and start-ups, financial literacy and the reduction of profit leakage.

The novelty and practical results of investigation: The importance of the impact of modern technologies and innovations on business development is also explained. The problems of business, which can hinder the diversification of the economy, were considered.
\end{abstract}

Key words: economic, SMES, Azerbaijan, industry, employment, migration

JEL Classification:

*Corresponding author: cemile.hasanova@unec.edu.az, ORCID 0000-0001-8004-5898 


\section{Introduction}

World practice shows that small and medium business in civilized forms is an important condition for the recovery of not only the economy, but also the entire social life. Analyzing the state of our republic's economy after gaining independence, we can observe periods of decline, stagnation and economic stabilization, when small and medium business is the most acceptable form of economic activity, which gained a dominant position in the market. It is able to react quickly to the changes taking place in the market and switch to the production of new goods and services; it is able to meet the market demand in an appropriate way and is able to survive in conditions of shortage of raw materials, capital, information, etc. But today this sector is developing in a relatively contradictory way.

\section{Literature Review}

The foundations of the investigation of entrepreneurship are laid in the works of foreign economists such as R. Cantillon, F. Knight, I. Schumpeter, F. Hayek, J. Say and others. These works mainly study the organizational and economic side of small business activity.

\section{Basic stages of SMES in Azerbaijan. Structure of SMES in Azerbaijan}

Referring to the innovative practice, mostly "average quantity of employees and yearly income determines classification of present enterprises by small, medium and large classes. If any of the criteria surpasses its parameters, the company's classification is changed to a higher level. For new enterprises, small, middle and large enterprises are classified built on "average number of workers" one year afterward the date of state registering and tax recording. In adding, built on a new order, the total quantity of total goods and services of the company is added to the yearly revenue for the financial year.

Table 1: Criteria of determination of SMES in Azerbaijan

\begin{tabular}{|l|l|l|}
\hline $\begin{array}{l}\text { Entrepreneurship } \\
\text { Category in terms of } \\
\text { size }\end{array}$ & Average Number of Employees & Annual Revenue \\
\hline Small & Up to 25 employees & Up 200 thousand manat \\
\hline Medium & Between 25-125 employees & $\begin{array}{l}\text { Between 200-1.250 thousand } \\
\text { manat }\end{array}$ \\
\hline Large & More than 125 employees & More than 1.250 thousand manat \\
\hline
\end{tabular}

Source: AR Cabinet of Minister's order 21 December, 2018, URL: http://www.e-qanun.az/41048

As for new enterprises, a year afterward the day of their government registration and tax accounting, SMES are classified based on their "average amount of workers". In addition, based on the new order, the total value of all of the enterprise's goods and services through the one fiscal year is added to its annual profits.

Micro, small and medium firms were determined according to the criteria on micro, small, medium and large entrepreneurs (Table 2) approved by the outcome by the Cabinet of Ministers of the State of Azerbaijan dated December 21, 2018, № 556.

Micro business includes enterprises with an average amount of employees of 10 persons, annual income to AZN 200 thousand up. Small business is considered an economic entity with an average amount of employees from 11 to 50 people; annual income ranges from AZN 200 thousand to 3 million. Among the medium enterprises are entrepreneurs whose 
annual income is from 3 million manat to 30 million manat, the number of employees is from 51 to 250 people.

Table 2: Criteria of determination of SMES in Azerbaijan in terms of income

\begin{tabular}{|l|l|l|}
\hline & Annual income & Number of Employees \\
\hline Small enterprises & $200000-3000000$ AZN & $11-50$ \\
\hline Medium enterprises & $3000000-30000000$ AZN & $51-250$ \\
\hline
\end{tabular}

Source: AR Cabinet of Minister's order 21th December, 2018, URL: http://cesd.az/new/wpcontent/uploads/2017/11/CESD SME Paper 2017.pdf

There is no certified definition of medium size legal entities in Azerbaijan. SMES are classified as small enterprises, while legal entities are also classified as small or all other entities that make up the SMES sector. Therefore, with the exclusion of large companies, all other registered enterprises fall below the group of SMES.

In the country, small and medium-sized enterprises are defined as commercial enterprises in which the share capital is equal to the percentage of participation of the Azerbaijan Republic, public and religious associations, of charitable and other foundations does not exceed $25 \%$. The percentage that belongs to one or more entities that are not small and medium business entity, not exceeding $25 \%$ and where the average amount of personnel of employees at no more than maximum limit levels: in industry, construction and at transport - 100 people; 50 in retail and consumer in other industries and other activities -50 person. From Table can be observed that the number of registered enterprises amounted to 244883 thousand objects in 2018.

According to the information provided by the Ministry of Economy of the State of Azerbaijan 2017, amount of entrepreneurship subjects in all sectors of the economy were numbered 794,441. As it turns out, in 2016, the number of entrepreneurship subjects increased by 77,179 , as compared to 2015 .

According to the Ministry of Economy of the State of Azerbaijan for January 01, 2018, number of all business objects in all spheres of the economy is 913,035 .

Table 3: The number of acting micro, small and medium entrepreneurship subjects

\begin{tabular}{|l|l|l|l|}
\hline \multirow{2}{*}{ Indicators } & $\mathbf{2 0 1 8}$ & \multicolumn{2}{l|}{} \\
\cline { 2 - 4 } & Total & \multicolumn{2}{l|}{ of which } \\
\cline { 3 - 4 } & & Legal persons & Individual ent. \\
\hline Total number of entrepreneurs & $\mathbf{2 4 4 8 8 3}$ & $\mathbf{2 6 3 8 9}$ & $\mathbf{2 1 8 4 9 4}$ \\
\hline The number of micro entrepreneurs & 237815 & 19321 & 218494 \\
\hline The number of small entrepreneurs & 4930 & 4930 & - \\
\hline The number of medium entrepreneurs & 2138 & 2138 & - \\
\hline
\end{tabular}

Source: The Government Statistical Committee of the Republic of Azerbaijan, 2018, URL: https://www.stat.gov.az/source/entrepreneurship/?lang=en 
Compared to the data for 2017 (792,764), the number of entrepreneurial objects has increased by 120,271 . When viewed as a percentage, the growth is $15.1 \%$ (Graph 1).

Graph 1: Number of registered SMES annually

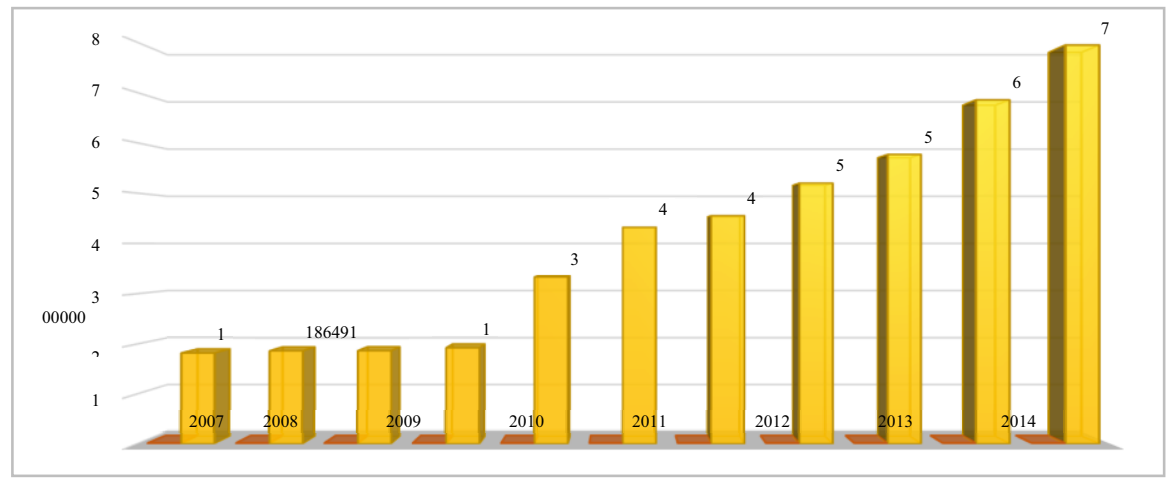

Source: Ministry of Economy of the State of Azerbaijan for 01 January 2018, https://economy.gov.az//uploads/fm/files/Sahibkarl $\% \mathrm{C} 4 \% \mathrm{~B} 1 \mathrm{q} \% 20 \mathrm{r} \% \mathrm{C} 9 \% 99 \mathrm{q} \% \mathrm{C} 9 \% 99 \mathrm{ml} \% \mathrm{C} 9 \% 99 \mathrm{r}$ d\%C9\%99\%202017.pdf

\title{
Distribution of small enterprises by economic region in Azerbaijan
}

As can be seen from Figure 4, most of the SMES are registered in Baku $-45 \%$. About $11 \%$ of objects - in Ganja-Gazakh region. 4\% - in Guba-Hachmaz region, 15\% in Aran zone. In Nakhchivan Autonomous Republic - 3\%. Smallest number is registered in Garabakh and Kalbajar-Lachin districts (for political reasons).

Figure 1: Distribution of SMES by economic region in Azerbaijan

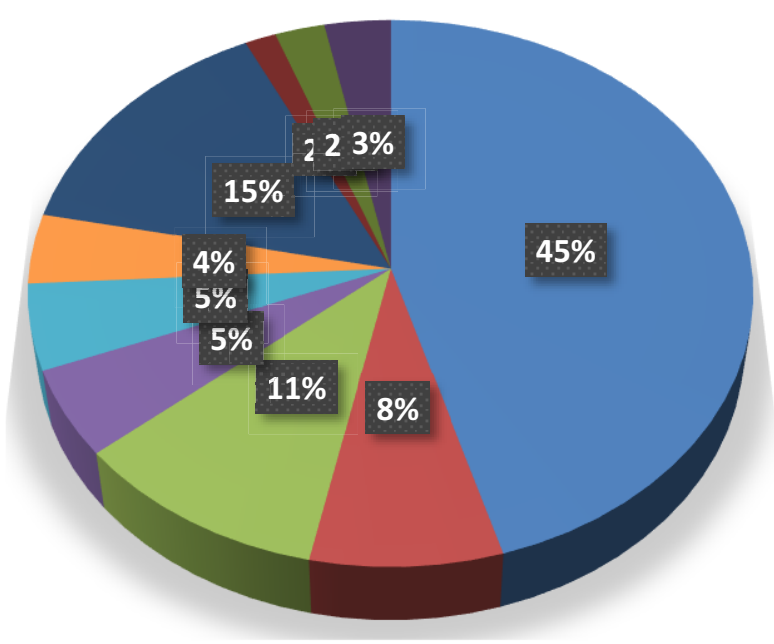

\author{
Baku city \\ Absheron economic region
Ganja-Gazakh economic region \\ - Sheki-Zaqatala economic \\ region \\ - Lankaran economic region
}

Source: The State Committee of Statistics of Azerbaijan 2018, URL: https://www.stat.gov.az/source/entrepreneurship/?lang=en

A typical feature of SMES in Azerbaijan is that they are situated in the capital city and in 
the Absheron region, and do not smear to other regions of the republic. As a result, business activity in the regions has not enhanced compared to Absheron and Baku. Therefore, the whole quantity of small enterprises in Baku, Sumgait and Ganja is $56 \%$ of the whole number of small enterprises in the republic.

Financial opportunities in Baku, lack of jobs in some regions and low profitability in agriculture generate seasonal employment and migration. Therefore, Baku, followed by Sumgait and Ganja, remains the most thickly populated city in the country.

Directions of activity of SMES in Azerbaijan

We can see clearly in the figure belove that, the most of the SMES's are engaged with the trade and the retail trade is nearly half of whole SMES share in Azerbaijan. It is possible that the reason for that condition is that the lack of institutions and the weak development of consumption enterprises. Data gained from Statistical reports shows that total number of acting enterprises is 248823 nearby.

Table 4: Number of acting, new created entrepreneurship subjects by economic activity types

\begin{tabular}{|c|c|c|}
\hline $\begin{array}{l}\text { Types of economic } \\
\text { activities (2018) }\end{array}$ & $\begin{array}{l}\text { The number of } \\
\text { entrepreneurship subjects } \\
\text { in action }\end{array}$ & $\begin{array}{l}\text { New created } \\
\text { entrepreneurship } \\
\text { subjects }\end{array}$ \\
\hline $\begin{array}{l}\text { Total for categories of } \\
\text { economic action }\end{array}$ & 244883 & 83346 \\
\hline \multicolumn{3}{|l|}{ of which: } \\
\hline $\begin{array}{l}\text { Agriculture, forestry and } \\
\text { fishing }\end{array}$ & 3122 & 9509 \\
\hline Industry & 9369 & 1770 \\
\hline Construction & 3811 & 1608 \\
\hline Trade; repair of transport & 76777 & 13497 \\
\hline $\begin{array}{l}\text { Transportation and } \\
\text { storage }\end{array}$ & 39867 & 9757 \\
\hline $\begin{array}{l}\text { Accommodation and } \\
\text { service activities }\end{array}$ & 18307 & 2673 \\
\hline $\begin{array}{l}\text { Information and } \\
\text { communication }\end{array}$ & 3398 & 750 \\
\hline Real estate activities & 5298 & 524 \\
\hline Education & 3225 & 1361 \\
\hline
\end{tabular}

In addition, another cause for the unequal development of the SMES in different sectors is monopoly in retail sectors. 
Figure 2: Number of acting, entrepreneurship subjects by economic activity types

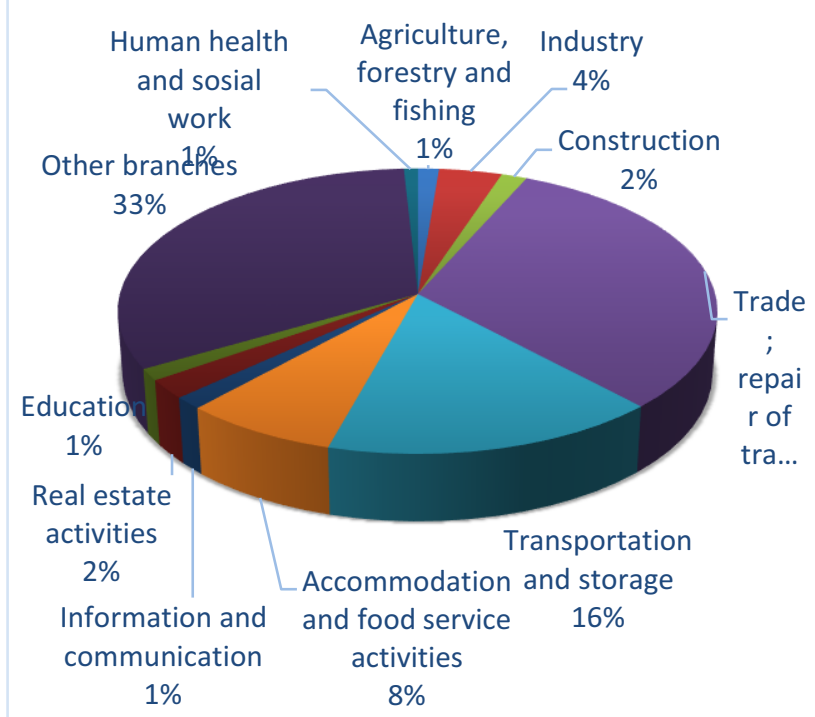

Agriculture, forestry and fishing

Industry

- Construction

Trade; repair of

transport means

Transportation and storage

Accommodation and food service activities

Source: Ministry of Economy of the Republic of Azerbaijan for 01 January 2018, URL: https://economy.gov.az//uploads/fm/files/Sahibkar2017.pdf

As revealed in Figure 3, the main share in the distribution, at $31 \%$ of small entrepreneurship subjects are registered in trade. $16 \%$ belongs to the transportation sector, $1 \%$ apiece to construction and real estate activities, only $2 \%$ to health and education field.

It comes to result that the majority of SMES are focused in low value-added areas as trade and reparation of automobiles, transport and storage, accommodation and cafes and services. This explains low involvement of SMES to the economy.

The sphere of trade and repair and cargo transportation occupies the leading positions. The smallest number is registered in the field of well-being and education. Also striking is the detail that the field of innovation and technological inventions are not in a separate line because of the small number of objects.

\section{Common problems and current difficulties, barriers affecting economic growth}

The analysis of the economic situation in Azerbaijan displays a major growth in the role of SMES, which characterize the most vital strategic resource capable of confirming economic growth. In the period of renovation, the expansion of SMES contributes to the formation of the market construction and the competitive environment, to the development of the manufacture of goods and services and their saturation in the marketplace, to a decrease in the number of jobless, and to the solution of central difficulties.

By its nature and peculiarities, it is more appropriate to develop entrepreneurship in Azerbaijan. As a law, SMES are less capital-intensive and acclimate further quickly to market conditions. Though enterprises fail, many of new SMES do not cause complications.

The factors that make it difficult for both large enterprises and individual business owners in various states can be separated into several groups:

Endogenous factors that hinder the expansion of business - in the first place, these difficulties occur at the levels of the microenvironment of the firm.

Exogenous factors - external problems in the growth of SMES and government measures 
to overcome them.

Internal factors include problems that exist within a single company and depend on management policy.

Let us consider the key elements of the internal and external environment problems of the firms in Azerbaijan. The complexity of the internal environment of the company structured in the following criteria:

- Absence of knowledge in the sector of market economy at managers of the company;

- Incompetent personnel;

- Poor organization system;

- Ineffective marketing policy;

- High expenses on payment of taxes and fees;

- $\quad$ Fixed costs that reduce profits;

- Absence of necessary financial resources for organization development.

It is possible to cope with inside difficulties under condition of effective regulation of company's activity by the administration or with the assistance of consulting services of audit companies from outside.

Now let us look on external problems that can be observed on firms:

- Rigid nature and unpredictability of the tax legislation of the country;

- Large monopolists in certain market segments;

- Lack of state support;

- Lack of electronic registration and regulation system.

- Other barriers affecting the growth of SMES involve also involves:

- Weak credit opportunities;

- Long working week;

- Weak social security of workers;

- Corruption by representatives.

Agreeing to the Islamic Cooperation for the Growth of the Private Sector (ICD), the core limitations of SMES expansion in Azerbaijan are admission to finance, tax rate and bribery. Survey information of ICD shows that access to finance is vital, and the amount of persons reporting it as a main restraint is $9 \%$ upper than the world average, at $16 \%$ (Islamic Corporation for the Development of the Private Sector, 2012). 
Table 5: The main problems of private enterprise in Azerbaijan

\begin{tabular}{|c|c|c|c|}
\hline Taxes & $\begin{array}{l}\text { Administrative } \\
\text { barriers }\end{array}$ & Legislation & $\begin{array}{l}\text { Difficulties in } \\
\text { obtaining and high } \\
\text { rate for a loan }\end{array}$ \\
\hline Political situation & $\begin{array}{l}\text { Lack of production } \\
\text { space, offices }\end{array}$ & Corruption, bribe & $\begin{array}{l}\text { Lack of material } \\
\text { base, resources }\end{array}$ \\
\hline $\begin{array}{l}\text { Monopoly of the } \\
\text { state, state } \\
\text { enterprises }\end{array}$ & $\begin{array}{l}\text { High prices for raw } \\
\text { materials }\end{array}$ & $\begin{array}{l}\text { Reporting } \\
\text { difficulties }\end{array}$ & Insurance issue \\
\hline Lack of equity & Competition & Staff problems & $\begin{array}{l}\text { Lack } \\
\text { information }\end{array}$ \\
\hline
\end{tabular}

Source: CESD report, 2017, URL: http://cesd.az/CESDResearchPaperAzerbaijanEconomy2017.pdf

\section{Administrative barriers}

The issue of administrative barriers is a serious problem. Trying to legalize the process of "participation in profits", local officials under the pretext of fighting against one-day firms and even terrorist threats insistently recommend furthering bureaucratizing the procedure of registration of small businesses. Undoubtedly, this will lead to growth in the already exorbitant "corruption" tax on business. It opposed by increasing the role of business unions and associations, continuing administrative reform and transferring some issues related to regulation of small business entities to public organizations of entrepreneurs. It is along this path that small business is developing all over the civilized world.

The administrative barriers that are observed in Azerbaijan can be shown as follows: licensing of certain types of activities; inter-regional trade turnover; certification and standardization of products, works and services; placement of orders for public and private needs. Work to eradicate administrative obstacles should focus on procedures where the maximum impact can be achieved by regional authorities. That is, first and foremost, procedures governed mainly by regional regulations. The second direction is control by regional authorities over the activities of territorial units.

\section{Economic growth}

At present, the owners of many middle class companies in Azerbaijan do not feel interested in economic growth. When such firms receive funds from the government budget aimed at business development, they spend them fairly inefficiently. This, in turn, leads to the result that money flows from the budget "into nowhere", while the problems of SMES development remain unsolved.

\section{Difficulties in obtaining and high rate for a loan}

In Azerbaijan, SMES have a limited chance to apply commercial banks credits. One reason for this comment is that the interest rates offered by banks are actual high, specially while banks favor short-term loans, which test the balance of payment of SMES. Even if Azerbaijani regulation permits the construction of security benefits of movable and immovable property, but banks hardly prolong finance protected by movable assets, excluding recorded movable property as automobiles, vessels, securities. Non-secured collateral, which enables the debtor to store tools and use it as warranty, is an important feature of the modern secured connections system, which is not established in Azerbaijan due to the absence of a warranty registry with not having supportive permitted framework. In most cases, banks require collateral in the form of real estate, which complicates the 
financial situation of small and medium-sized businesses. (In Azerbaijan, the loan interest rate varies between $14-20 \%$ if local currency is taken. The rate on loans in dollars is from $9 \%$. Loan repayment term is from 3 to 60 months)

Overview by the International Finance Organization (IFC, 2009) has shown that, in Azerbaijan, banks are not eager to give credits to SMES because of their low probability of repayment in the situation of insolvency (CESD, 2017).

The World Bank reports to access necessary funding mentions that the upper three named difficulties in setting up a firm in Azerbaijan are: difficulty finding the needed funding, huge opening investment and struggle finding business associates (World Bank, 2013).

On average, the start-up capital for starting business activity in our country is about 20 thousand manats. However, the difficulty lies in obtaining loans from banks at high interest rates, reaching $27-30 \%$ per annum. Undoubtedly, unfavorable conditions for granting credits make entrepreneurs cautious and refuse from business projects. After all, expensive credit makes expensive cost and sales value of its services or goods.

\section{Insurance issue}

Many individual entrepreneurs and small enterprises do not pay much attention to insurance of their goods and facilities. This creates difficulties in the idea of compensation. Over the past year, we can cite two major examples - the fires at the outlets of Euro Home and Diglas, where a great amount of entrepreneurs have lost their goods. The government's need to provide assistance in such disasters is fair. However, if we take into explanation that compensation payments are high and weaken the budget, then correct and timely insurance of their objects by entrepreneurs is necessary and sometimes obligatory. This in turn will allow the insurance market in Azerbaijan to develop in parallel, which will lead to economic progress in the country. One of the approaches to solving these issues is to inform individual entrepreneurs, carry out certain social projects, as the interest of insurance companies in expanding the portfolio of their clients.

\section{Lack of financial resources-equity}

SMES at the first stage face the problem of financing their projects and ideas, as the lack of clear concepts about tax laws and orders of the country's authorized persons in this problem. Comparable analysis of Eastern Partnership (EaP) nations displays that, in Azerbaijan, the majority of companies are built by businesspersons own funds and commonly, the trend continues through the life of the enterprises. According to this point, Azerbaijan falls far behindhand other EaP nations.

\section{Tax problem}

Analyzing tax payments to the republic's budget, in agreement with the law of Azerbaijan, SMES are not payers of value added tax (VAT). They are payers of simplified tax in $4 \%$, as the yearly turnover does not surpass 200 thousand manats. However, despite this, numerous entrepreneurs are trying to hide the revenue of their facilities, masked as cash. Over the past three years, more than 400 amendments and additions made to the tax legislation. This poses a serious problem for SMES. It takes a long period to adapt to each new rule, while businesspersons cannot strategy their business in the long term.

The rate on simplified tax for persons representing goods or services in Baku is $4 \%$, in other regions - 2\%. Persons involved in passenger transportation are taxed AZN 1.8 per seat. People engaged in transportation of people by taxi pay AZN 9, the tax for transportation of goods is AZN 1 for each ton. The main purpose of the simplified tax is to decrease the tax burden for persons engaged in small business, as well as reduce the administrative burden and exception from additional documentation. However, looking to tax reports of Azerbaijan Republic was noted that recently some entrepreneurs had used the simplified tax to pay less. Large enterprises split their business into several smaller companies in order to become the payers of the simplified tax, therefore avoiding the payment of other taxes. Such companies are exempt from VAT, income tax and property tax, while individuals do not pay VAT and 
income tax.

In some cases, businesspersons working in Baku (in the capital until 2019 the simplified tax rate was $4 \%$ ) recorded their business in the regions to pay $2 \%$ (the simplified tax rate for districts). Thus, they formed serious difficulties for tax accounting. As a result, over $90 \%$ of taxpayers recorded in the country are currently subject to the simplified tax. The share of this tax in tax revenue is just over 5\%, while in many republics it is around $40 \%$.

According to the amendments, as of 2019, persons with more than 10 workers involved in the wholesale of gold and jewelry, leather goods, as persons engaged in licensed activities (except for the structure of buildings), pay the simplified tax. From this year onwards, these taxpayers will pay income tax. Thus, from January 1, 2020 the simplified tax for persons engaged in the construction of buildings abolished, the tax liabilities of these persons performed by a single method - as a payer of VAT and income tax (http://www.etaxes.gov.az, 2019).

In addition, prior to the changes, taxpayers of the simplified tax did not have to register their income and expenses, because the tax on goods (works and services) calculated without deduction of expenses, and therefore reporting was not done properly.

Individual entrepreneurs, working based on public law agreements, will pay taxes on income from this year, taking into explanation the benefits, the ministry said. Namely, $75 \%$ of income and profits of micro-entrepreneurs are exempt from taxation.

So, let highlight the main problems of the tax system in relation to SMES:

- Constantly changing tax legislation;

- Complexity of the adopted laws in the sector of taxation;

- $\quad$ Large size of taxes charged;

- Undeveloped service for organizing the work of tax authorities.

As for the positive qualities of taxation of SMES in Azerbaijan, business in certain types of activities as innovative technologies, knowledge-intensive and high-tech industries has some tax benefits.

\section{Staff issue}

Amount of small enterprises face a personnel problem. Nowadays in Azerbaijan, there is a "change of generations of the director corps" of innovation. Experienced personnel are leaving, while the young ones lack experience in this sphere. The value of education of young specialists is beyond doubt, but the newcomers lack the skills to run large innovation projects, which only the "old" generation has.

In addition, depending on different conditions, employees agree to work without an employment contract, although it is not in accordance with the law of Azerbaijan Republic. Because of this, payments of social contributions to the state treasury reduced, many people deprived of the right to pension. The presence of "black accounting" at facilities creates conditions for cash leaks and is an obstacle to the establishment and application of new electronic world standards for non-cash payments.

\section{Lack of culture, experience}

East Survey Index (2012), initiate that, in Azerbaijan, closely no SMES have an intent to gross a credit from universal donors or worldwide financial organizations. A rational explanation for this shortcoming may be a lack of financial literacy on the field of Azerbaijani entrepreneurs. Financial knowledge gaps distress equally demand and supply; it moves demand, while SMES with deprived information of commercial facilities, available goods and business groups are fewer expected to apply for subsidy. It moves supply, as little commercial knowledge produces obstacles and misinterpretations among financial organizations and clients (CESD, 2017). 
In Azerbaijan, the low marketplace relevance of normal teaching, the inactivity of the informative system in response to the varying demands of the work market make changes problematic. Therefore, there is a crack between the desires of the innate work market and the proficient experiences of the labor force, ensuing in an absence of sufficiently skilled workers and a staff to the local and national market.

\section{Lack of information systems}

Additional difficult is the underdeveloped information support system for SMES. The market of accessible information systems today has only a narrow range of information about government support measures, about lending and leasing services, about probable investors, new technologies and equipment. The problem of SMES, which have quite a serious intellectual potential, as a rule, is that they need expensive material and technical base to create examples. The practical inaccessibility of investment and information resources exaggerates the problems of SMES, contributes to the reduction of their actions or the transition to the shadow economy.

\section{Monopoly}

Today, monopoly is one of the chief difficulties to the development of the republic's economy as a whole. Business turnover with officials hinders the progress of SMES in Azerbaijan. The oligarchy, which controls various areas, prevents small and medium players from entering the markets. There are hundreds of examples in Azerbaijan. Therefore, it is required to keep officials away from business. If officials do not leave the business, they will not be able to develop any sector of the economy.

\section{Limited markets (domestic and international)}

Insufficient information on market awareness is additional constraint on the viability of local small businesses. Agreeing to the Central Bank of Azerbaijan (CBAR) and the Agency for the Monitoring of Financial Markets (FISA), the size of joint-stock businesses in Azerbaijan is only $1 \%$ of GDP, and the volume of bonds is only $7 \%$ of GDP, which means the progress and development of small enterprises. (president.az, 2016)

\section{Corruption}

Azerbaijan has been addressing the corruption challenges in a diversity of ways over the past decade, as revealed also by the Transparency International's Corruption Perception Index, where Azerbaijan's score has been progressively improving over the past five years from 27 to 31 (100 being best and 1 worst), though from a low base. In 2017, the republic detained 122nd places globally among 180 countries, with the score of 31 .

Today there is no healthy competition in the market, small and medium persons sometimes have to pay "for roofing". However, it should be understood that the bureaucracy hinders the development of this industry, the increase in the share of which indicates a stable development of the economy.

Nowadays, Azerbaijan is the 126 least shady nation out of 180 republics, according to the 2019 Corruption Observations Index reported by Transparency International (https://tradingeconomics.com/azerbaijan/indicators, 2019). 
Graph 2: Azerbaijan Corruption Level

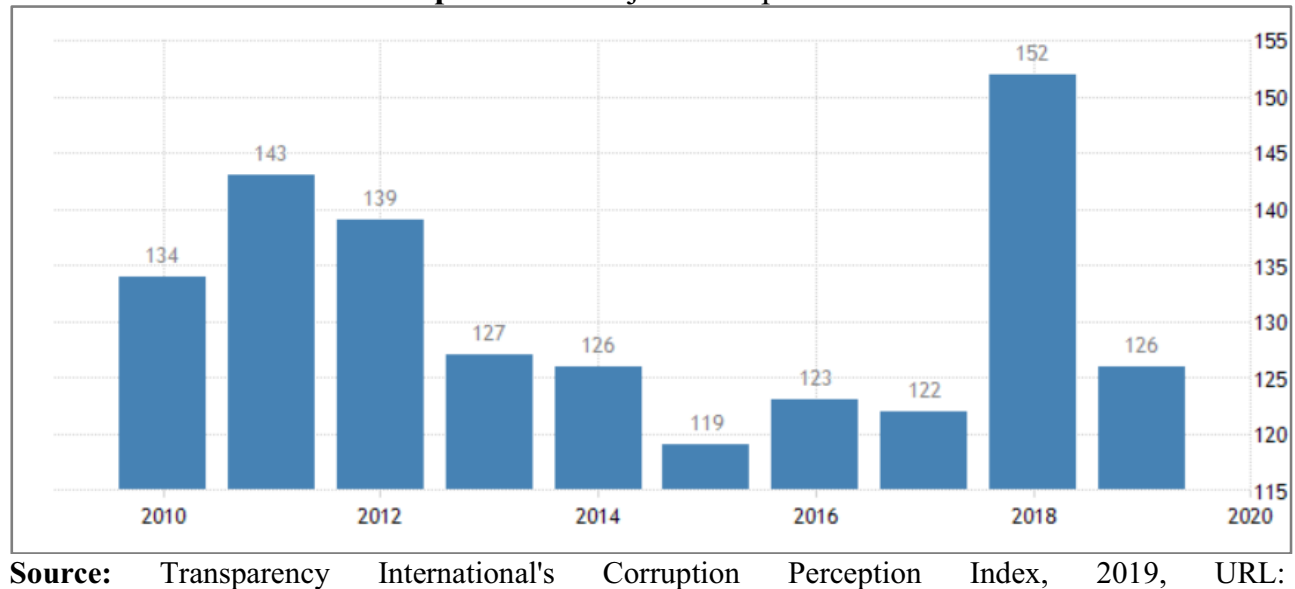

https://www.transparency.org/en/cpi/2019

The existence of bribery in the SME sector can be explained by the following fact that entrepreneurial initiative has been suppressed for generations in Azerbaijan, and all the power of the state for centuries has been directed to maintaining the power machinery. In the course of accelerated public, economic and governmental reforms, there are still no sustainable needs for honest business and law-abiding citizens. In addition, if the technology sector is widely applied in the country in the future, this problem can be eradicated.

\section{Lack of innovation}

Most businesses in Azerbaijan are engaged in production and trade. SMES are presented in the form of beauty hairdresser's, car washing places, restaurant business. Development of startups in the scope of services and technologies is a minority, which indicates dependence on exhaustible resources and is an obstacle in diversification of economic areas.

\section{Conclusion}

By analyzing local market of SMEs let to summarize some results.

Small firms provides essential flexibility in the market circumstances, generates profound concentration and cooperation, deprived of which its extraordinary effectiveness is unthinkable. It is able not only quickly fill the niches formed in the consumer sector, but also to pay off relatively quickly. It also creates a competitive atmosphere and the business environment, without which the market economy is impossible.

SMEs enterprises play a significant role in employment, the production of individual goods, research and development. The following reasons explain the victory of small businesses in this area. Deeper specialization in research and development has led that in many cases, small firms follow a simpler or riskier path, working in unpromising industries. Small firms are more willing to adopt original innovations. Small businesses are looking to establish mass production as soon as possible. This, above all, leads to the expansion of the market of properties and services offered, which in turn actively stimulates the production process in order to meet the demand as quickly as possible, motivated by developments conducted by micro businesses. SMEs, in their turn, are the backbone of large companies, since the mass production of industrial durable goods (cars, refrigerators, televisions, etc.) causes the need for appropriate industrial repair and maintenance services. After all, because of their cumbersomeness large monopolists are forced to spend a lot of effort in this direction or to create an extensive network of small branches, which in itself is also quite expensive, serving mainly to maintain the prestige of a large firm. 
Small firms meet the needs for scarce goods and services at a minor cost by developing local sources while providing more employment. By creating new jobs, unemployment and social tensions in the country are reduced.

Despite the advantages of entrepreneurship development in regional and local markets of the country, to ensure a competitive position in the market, sales volume and income, the entrepreneur should constantly improve the range of products in accordance with the growing needs of customers, which requires constant replenishment of working capital, and to modernize the production of investment resources.

At the current stage of Azerbaijan's economy, it is compulsory to develop all forms of entrepreneurship regardless of the size of the organization. The study shows that small and medium firms play a significant part in the entrepreneurship system in terms of generating favorable conditions for economic recovery, development of competitive environment, activation of additional jobs and expansion of the consumer sector.

Thus, small entrepreneurship leads to the recovery of the country as a whole, and therefore, the best way for Azerbaijan is to create a state policy aimed at expanding and emerging small businesses in our country.

In the dissertation work, the problems of SME development in Azerbaijan were considered, namely, tax and administrative barriers, presence of corruption at enterprises were studied. A structural analysis by region was conducted. Despite the state programs to help the regions develop, the level of entrepreneurship development in the regions lags behind the central cities. The analysis shows that despite the measures taken, small business in Azerbaijan is not yet sufficiently developed and needs additional support. The Government is trying to level the situation, to attract the poor, people with disabilities, university graduates, rural housewives, etc. to business. In the regions, the Ministries of Taxes, Labor and Social Assistance, Economy and Industry carry out awareness-raising activities. Alas, however, the share of small and medium-sized firms in the country is still critically low. Today the share of small business in the country's GDP is only $15-20 \%$.

Azerbaijan's business environment suffers from informal economy, prevalent fraud, and holding firms that govern important shares of the non-oil economy. But also it has opportunities such as increasing financial opportunities, the possibility of creating private credit bureaus, increase utilization potential of SMEs in development non-oil sector; involvement of SMEs in public procurement and projects infrastructure; establishment of centers providing consulting services and outstanding necessary documents from a single places for SMEs; diversification of production areas diversification of the economy; availability of potential labor. Therefore, it is compulsory to correctly apply these points together with the cooperation of firms and the state.

Studies have shown that in direction to recover the economy, creation of favorable conditions, development of competitive environment, restructuring of additional jobs in terms of activation and expansion of the consumer sector, SMEs play an central character in the entrepreneurial system.

In my opinion, to the conclusion that regardless of the programs implemented by the state in SME development, the main problems come from the internal environment of enterprises. SMEs should adopt the experience of functioning of strong enterprises, their corporate culture. Even where start-up capital and finance are scarce, SMEs must now focus on developing technologies for service delivery and research and development.

Avoid the shadow economy, black accounting, and it is possible only with the competent training of their staff to do business by applying world standards.

\section{References}


1. Aliyev S., "Problems and Opportunities for Leveraging SME Finance through Value Chains in Azerbaijan", Asian Development Institute, ADBI Working Paper Series № 973, 2019,p.38

2. Annual Report of Ministry of Economic Development of Azerbaijan Republic, Baku, 2019

3. Annual Performance Report, FY Congressional Budget Justification, U.S. Small Business Administration, 2017

4. Bayramov V., Hasanov R., (2017), "A Comparative Study on Development of Small and Medium Enterprises (SMES) in Azerbaijan", Baku, "CESD Press", pp.35-66

5. Bayramov V., Hasanov R., (2010), "A Comparative Study on Development of Small and Medium Enterprises (SMES) in Azerbaijan", Baku, "CESD Press", pp.25-37

6. Babayev M.S., (2017), World experience in supporting small and medium-sized businesses in the establishment and development of a market economy

7. Country report, Azerbaijan. Investing in SMES in the Eastern Partnership 2018, pp.812

8. Development concept "Azerbaijan - 2020: a look into the future", Baku, 2020

9. European SME Bank, Development of small and medium enterprises. Foreign experience, 2016

10. European Commission 2018, General report on European States programs

11. European Commission for Economic Policy, EU policy framework on SMES: state of play and challenges, 2018

12. European SME. Going digital. The Challenges Facing European SMES. Survey 2019

13. Hart M., Lenihan H., "SMES in a Globalized World: Survival and Growth Strategies on Europe's Geographical Periphery”, Economic Geography, 87(3), 2017, pp.367-368

14. Hansjörg H., Nettekoven Z.M., (2017), "The Role of Small and Medium-sized Enterprises in Development", Berlin, Friedrich-Ebert-Stiftung, p. 27

15. Kalinin A., "Analysis of development and condition of SMES in the world", Economics, entrepreneurship and law №4, 2017, pp. 3-12

16. Klaus N., Gregorio V., (2016), Competitive Strategies for Small and Medium Enterprises: Increasing Crisis Resilience, Agility and Innovation in Turbulent Times, ,London, Springer, p.362

17. Kondrakov P., (2019), Basics of small and medium business. Practical manual, Moscow, "Infra-M", p.446

18. Mammadli G. and Stasiak-Betlejewska, (2016), "Factors affecting success of SMES in Azerbaijan", Achieves of Engineering Knowledge vol.1, p.58

19. Musayev V., "Azerbaijan economic reforms review”, Center of Analysis of Economic Reforms, 2017, Baku, p.16

20. OECD Scoreboard, (2018), Financing SMES and Entrepreneurs

21. OECD Scoreboard, (2018), Driving Diversification through Strengthened Entrepreneurship/Azerbaijan

22. Powell P., Levy M., (2018), Strategies for Growth in SMES explores for the first time the role of information and information systems, "Elsevier Ltd", p.420

23. PwC, Doing Business report / Economy Profile Azerbaijan, Baku, 2019 , p.7

24. United Nations Conference on Trade and Development report, Improving the competitiveness of SMES through enhancing productive capacity report, Geneva, 2003

25. Vanhaverbeke W., (2018), Researching Open Innovation in SMES, USA, "World Scientific Publishing Co. Pte. Ltd", p.497

26. World Bank group, "Economy Profile Azerbaijan”, Doing Business report 2020 